\title{
APLIKASI KAMUS BAHASA SASAK HALUS MENGGUNAKAN ANDROID
}

\author{
Khairunnazri'), Muh. Fahrurrozi' $^{2)}$, Lalu Puji Indra Kharisma ${ }^{3)}$ \\ ${ }^{1,2,3)}$ STMIK Syaikh Zainuddin NW Anjani NTB \\ e-mail: $\underline{\text { m4sterlenk@gmail.com }}{ }^{1)}, \underline{\text { f4.rozi@gmail.com }}{ }^{2}$, $\underline{\text { lalupujii@gmail.com }}^{3)}$
}

\begin{abstract}
ABSTRAK
Bahasa Sasak adalah salah satu bahasa daerah yang digunakan untuk berkomunikasi oleh masyarakat Lombok, Nusa Tenggara Barat. Namun seiring dengan berkembangnya teknologi khususnya di bidang Smartphone Android, Bahasa Sasak sudah mulai pudar, tak sedikit orang Lombok yang tidak mengerti bahasa, kosa kata Lombok Sasak apalagi generasi sekarang. Hal ini disebabkan oleh faktor lingkungan keluarga, sekolah dan temanteman yang menggunakan bahasa Indonesia dalam percakapan sehari-hari.Solusi untuk masalah ini adalah merancang sebuah aplikasi kamus Sasak Halus berbasis Android. Tujuan utama aplikasi kamus Sasak Halus adalah untuk membantu mereka dalam menemukan terjemahan bahasa Indonesia atau bahasa Sasak Halus secara efektif dan efisien dengan media smartphone. Aplikasi kamus berbahasa Sasak Halus berbasis android berbasis APPS berbentuk installer yang bisa digunakan pada smartphone berbasis Android dengan versi minimal 4.00 ke atas Dalam pengujian menggunakan pengujian kotak hitam dan uji coba pada smartphone, aplikasi bisa berjalan lancar.
\end{abstract}

Kata Kunci: Kamus Bahas Sasak, Kamus Bahasa Sasak Halus, Kamus Bahasa Indonesia Sasak

\section{ABSTRACT}

Sasak Language is one of the regional languages used to communicate by the people of Lombok, West Nusa Tenggara. But along with the development of technology, especially in the field of Android smartphones, the Sasak language has begun to fade, not a few people in Lombok who do not understand the language, Lombok Sasak vocabulary especially the current generation. This is caused by environmental factors of family, school and friends who use Indonesian in daily conversation. The solution to this problem is to design an Android-based Sasak Smooth dictionary application. The main purpose of the Sasak Halus dictionary application is to assist them in finding Indonesian or Sasak Halus translations effectively and efficiently on smartphone media. Sasak Fine-language dictionary application based on Android-based APPS in the form of an installer that can be used on Android-based smartphones with a minimum version of 4.00 and above. In testing using black box testing and testing on smartphones, the application can run smoothly.

Keywords: Library Sasak Language, Library Sasak Halus, Library Indonesia Sasak

\section{Pendahuluan}

$\mathrm{K}$ amus merupakan sebuah media yang dapat diartikan sabagai buku yang berisikan tentang arti suatu kata dari bahasa atau istilah asing [1]. Menurut Kamus Besar Bahasa Indonesia, Kamus merupakan buku acuan yang memuat kata dan ungkapan, biasanya disusun menurut abjad. Sekarang ini cukup banyak kamus yang beredar, mulai dari bentuk buku, kamus elektronik, aplikasi kamus berbasis dekstop dan web. Masing-masing kamus memiliki kelebihan dan kekurangan masing-masing. Kamus dalam bentuk buku memiliki kelebihan dalam hal jumlah kosa kata dan memiliki kelemahan dalam pencarian arti kata yang memakan waktu lama.

Bahasa adalah pengungkap segala realitas sebagaimana tampak pada tata permainan-permainan bahasa yang pada hakikatnya cerminan dari pluralitas kehidupan manusia itu sendiri [1]. Bahasa berbeda-beda dari segi lafalnya, menyatu dari segi makna yaitu makna satu yang mencakup beberapa kata ganti orang, seperti halnya Bahasa Sasak.

Bahasa Halus pada suku Sasak masih belum dipahami atau dikenal oleh sebagian besar masyarakat Sasak, karena sedikitnya media pembelajaran mengenai bahasa Halus baik itu berupa kamus maupun yang lain. 
Bahasa Halus pada suku Sasak hanya di pahami oleh orang-orang atau tokoh-tokoh tertentu seperti tokohtokoh masyarakat yang masih kental akan teradisi suku Sasak seperti tradisi Sorong Serah, Aji Krama pada upacara pernikahan, oleh karena itu perlu dilakukan penelitian untuk melestarikan Bahasa Halus Suku Sasak dikalangan Lokal, Nasional maupun Internasional.

\section{STUDI PUSTAKA}

\section{A. Pustaka}

Alfa Ilhami pada penelitiannya yang berjudul Rancang Bangun Aplikasi Kamus Bahasa IndonesiaBawean, aplikasi kamus bahasa indonesia-Bawean sangat berdampak dan mendapat respon positif dari masyarakat sekitar, khususnya kalangan siswa-siswi sekolah dasar (SD) di Bawean [2].

Intan Nur Farida pada penelitiannya tentang perancangan Aplikasi Kamus Indonesia-Jawa Berbasis Android. Penelitian yang dilakukan dilatarbelakangi oleh pesatnya perkembangan jaman dan teknologi sehingga dirancang aplikasi kamus yang menyajikan penerjemahan dari bahasa Indonsia ketiga tingkatan bahasa Jawa yaitu Ngoko, Karma Madya dan Karma Inggil bagi generasi muda yang tidak bisa berbahasa Jawa. Metode yang digunakan dalam penelitian adalah Squential Search dan JSON (Java Script Object Notation) [3].

Muhammad Fadlullah penelitiannya tentang Rancang Bangun Aplikasi Kamus Jerman-Indonesia Berbasis Android. Penelitiannya merancang kamus digital Jerman-Indonesia sebagai alat bantu bagi mereka yang sedang atau ingin belajar bahasa internasional yaitu bahasa jerman dalam menemukan kosa kata bahasa jerman. Metode pengembangan perangkat lunak yang digunakan adalah metode prototype, menggunakan bahasa pemrograman Java dan SQLite sebagai databasenya. Aplikasi yang dihasilkan hanya kompatibel dengan ponsel yang berbasis android dengan versi 2.2 dan selebihnya, hanya dapat menghasilkan terjemahan dalam bentuk kata bukan kalimat [4].

\section{B. Kamus}

Kamus merupakan sebuah buku referensi yang memuat daftar kosa kata yang terdapat dalam sebuah bahasa, yang disusun secara alfabetis disertai keterangan bagaimana menggunakan kata itu [5].

\section{Bahasa}

Bahasa adalah pengungkap segala realitas sebagaimana tampak pada tata permainan-permainan bahasa yang pada hakikatnya cerminan dari pluralitas kehidupan manusia itu sendiri [1].

\section{Android}

Android adalah sebuah sistem operasi mobile yang berbasiskan pada versi modifikasi dari linux. Pertama kali sistem operasi ini dikembangkan oleh perusahaan android.inc. Nama perusahaan inilah yang pada akhirnya digunakan sebagai nama proyek sistem operasi mobile tersebut, yaitu sistem operasi android [6].

\section{E. Android SDK (Software Development Kit)}

Android SDK (Software Development Kit) adalah tool dan alat bantu API (Application Programming Interfaces) yang diperlukan untuk mengembangkan aplikasi berbasis Android menggunakan bahasa pemrograman Java SDK sering juga disebut sebagai software emulator yang berguna untuk mensimulasikan OS Android pada PC [7].

\section{F. Embarcadero Delphi 10.2.3 Community}

Delphi merupakan aplikasi pemrograman dengan bahasa pascal. Delphi sekarang dikenal dengan Embarcadero Delphi. Sebelumnya Delphi bernama CodeGear Delphi, Inprise Delphi dan Borland Delphi, merupakan lingkungan pengembangan terintegrasi untuk aplikasi Microsoft Windows, awalnya dikembangkan oleh Borland dan sekarang dimiliki dan dikembangkan oleh Embarcadero Technologies. Tampilan IDE Delphi 10.2.3 Community dapat di lihat pada Gambar 1. di bawah ini sebagai berikut :

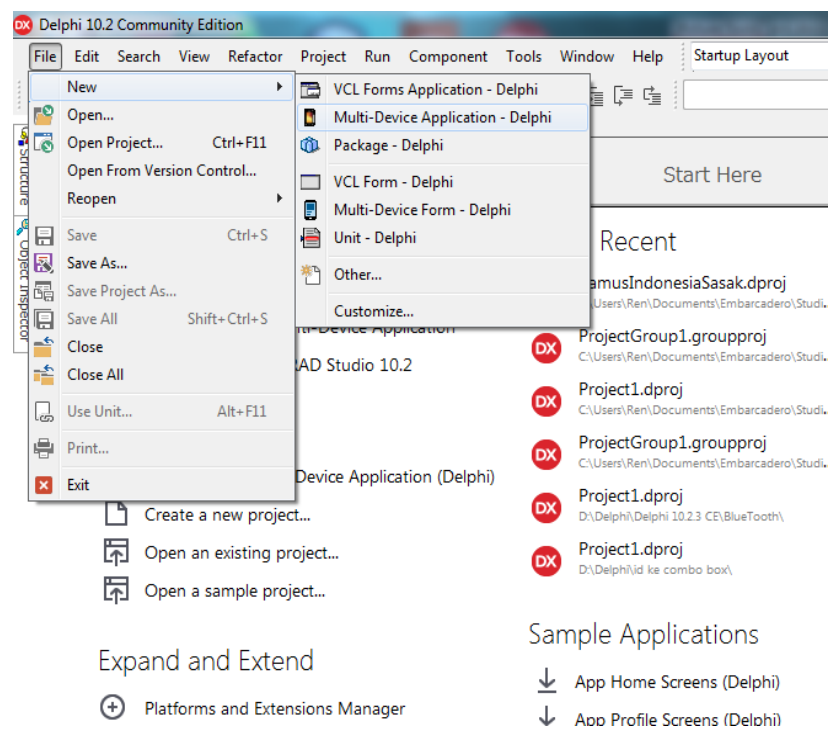

Gambar 1. IDE Delphi 10.2.3 Community

\section{G. SQLite Expert Personal 3}

SQLite Database merupakan interface yang ada pada sistem operasi android yang digunakan untuk membuat relational database. (Herman S, Stephanus,2011). SQLite Expert Personal 3 merupakan sebuah aplikasi Database Manajemen Sistem (DBMS) yang 
mengelola database SQLite, adapun Tampilan SQLite Expert Personal 3 dapat dilihat pada gambar 2 di bawah ini sebagai berikut :

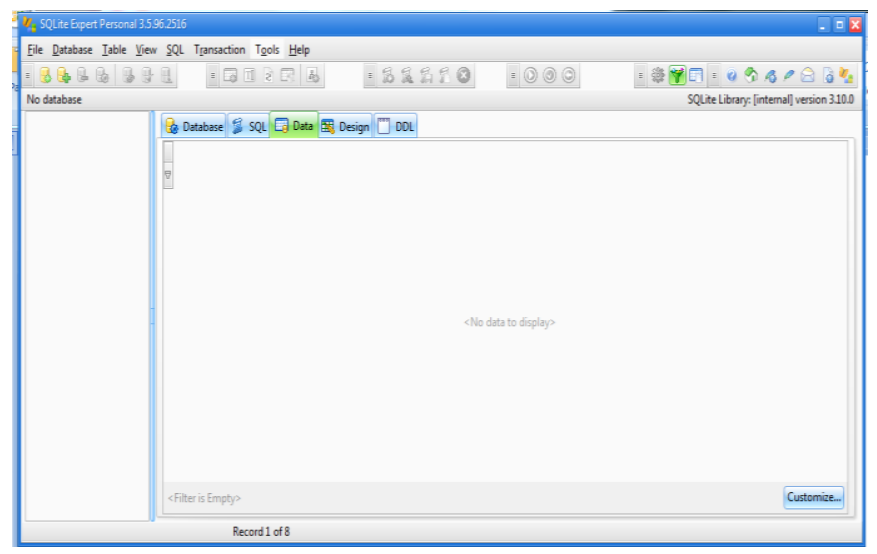

Gambar 2. SQLite Expert Personal 3

\section{METODE PENELITIAN}

\section{A. Use Case Diagram}

Use Case Diagram merupakan diagram yang menggambarkan hubungan antara aktor dengan sistem. Use case diagram bisa mendeskripsikan sebuah interaksi antara satu atau lebih aktor dengan sistem yang akan dibuat. Use case diagram juga bisa digunakan untuk mengetahui fungsi apa saja yang ada di dalam sebuah sistem dan bisa juga mempresentasikan sebuah interaksi aktor dengan sistem. Komponen tersebut kemudian menjelaskan komunikasi antara aktor, dengan sistem yang ada. Dengan demikian, use case dapat dipresentasikan dengan urutan yang sederhana, dan akan mudah dipahami oleh para konsumen. Manfaat dari use case sendiri adalah untuk memudahkan komunikasi dengan menggunakan domain expert dan juga end user, memberikan kepastian pemahaman yang pas tentang requirement atau juga kebutuhan sebuah sistem.

Secara umum gambaran perancangan Use Case Diagram Aplikasi Kamus Bahasa Sasak Halus, dapat di lihat pada gambar 3. di bawah ini sebagai berikut:

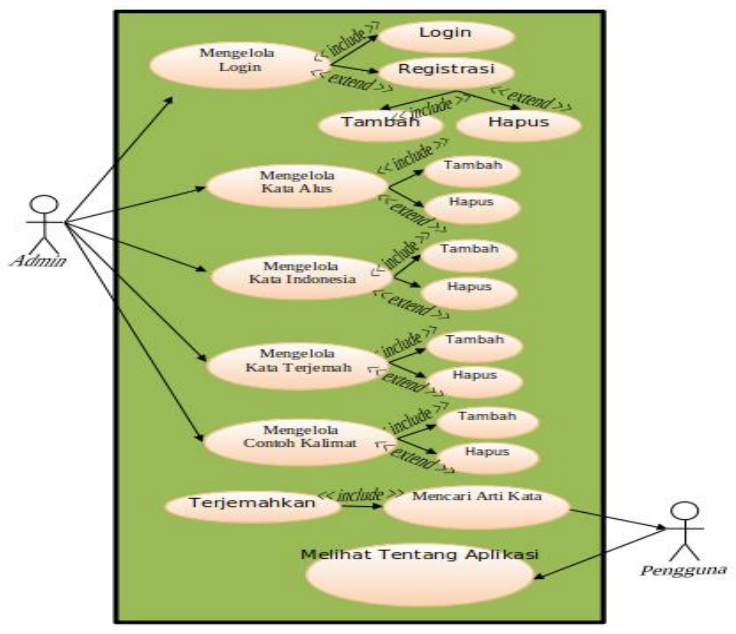

Gambar 3. Use Case Diagram Aplikasi Kamus Bahasa Sasak Halus

\section{B. Class Diagram}

Class Diagram merupakan salah satu diagram utama dari UML untuk menggambarkan class atau blueprint object pada sebuah sistem. Analisis pembentukan class diagram merupakan aktivitas inti yang sangat mempengaruhi arsitektur piranti lunak yang dirancang hingga ke tahap pengkodean. Pada Class Diagram juga digambarkan bagaimana interaksi hubungan antar class dalam sebuah konstruksi piranti lunak seperti hubungan asosiasi, agregasi, komposisi, dan inheritance dan generalization.

Class Diagram menggambarkan tentang class yang dibutuhkan dalam sebuah sistem. Setiap class memiliki nama, atribut dan operasi yang akan dilakukan. Class juga memiliki relasi antar class yang dimana menandakan hubungan antar class.

Gambaran Class Diagram Aplikasi Kamus Bahasa Sasak Halus, dapat dilihat pada gambar 4. di bawah ini sebagai berikut :
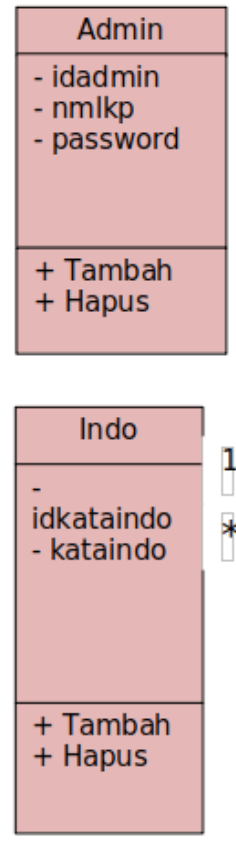

Gambar 4. Class Diagram Aplikasi Kamus Bahasa Sasak Halus

\section{Rancangan Struktur Program}

Adapun struktur menu program Aplikasi Kamus Bahasa Sasak Halus ini dapat dilihat pada gambar 5. di bawah ini sebagai berikut : 


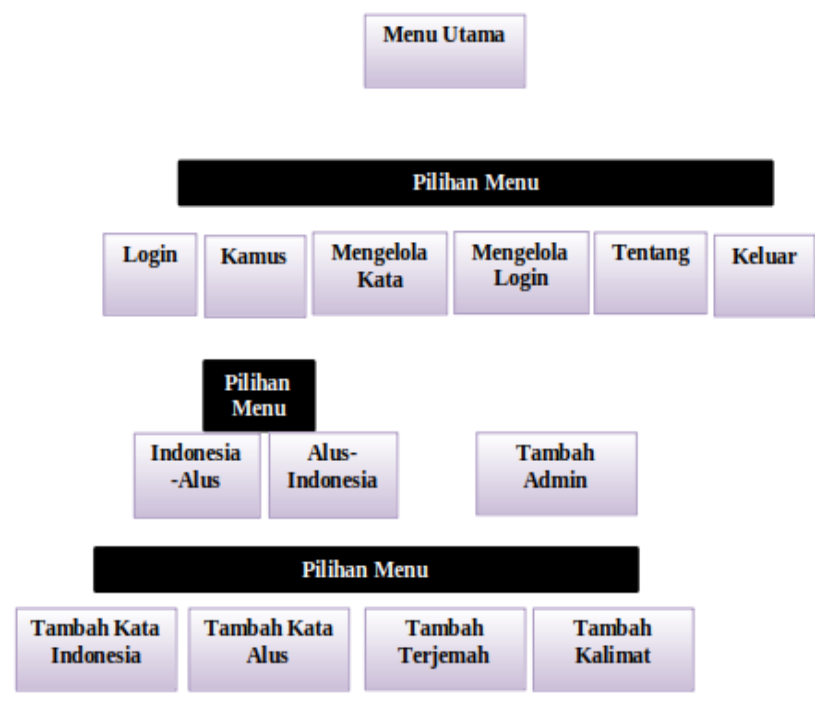

Gambar 5. struktur menu Aplikasi Kamus Bahasa Sasak Halus

\section{HASIL DAN PEMBAHASAN}

\section{A. Tampilan Awal Program}

Tampilan awal program pertama yang akan ditampilkan ketika aplikasi di jalankan pertama kali pada aplikasi desktop Android. Adapun tampilan awal program dapat dilihat pada gambar 6. di bawah ini sebagai berikut :

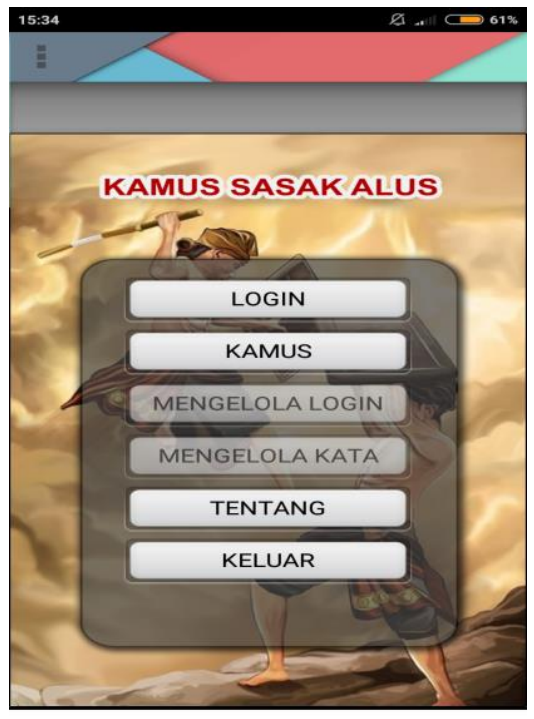

Gambar 6. Tampilan awal program

\section{B. Tampilan Menu Login}

Tampilan menu login merupakan tampilan dimana admin harus memiliki user name dan password, pada tampilan login terdapat dua tombol yaitu LOGIN dan BATAL. Adapun tampilan menu login tersebut dapat dilihat pada gambar 7. di bawah ini sebagai berikut :

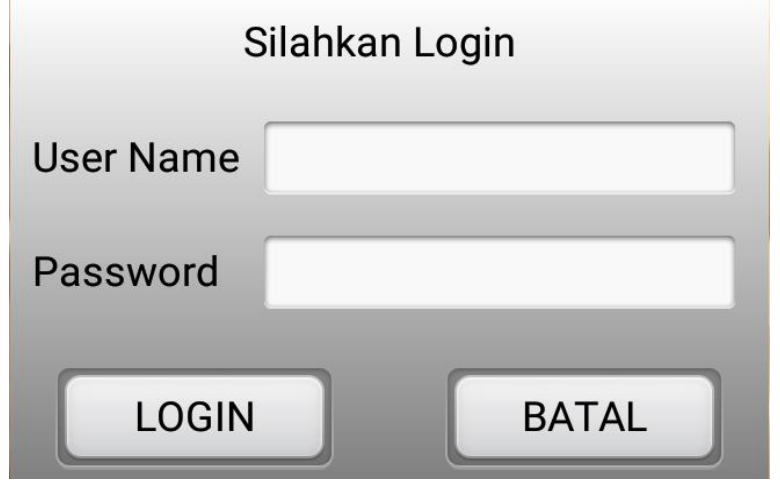

Gambar 7. Tampilan menu login

\section{Tampilan Mепи Kaтиs}

Tampilan menu kamus merupakan tampilan dimana user dapat mencari arti kata, baik itu kata dalam Bahasa Indonesia ke Bahasa Sasak Halus maupun sebaliknya yaitu dari kata Bahasa Sasak Halus ke Bahasa Indonesia. Pada tampilan kamus user harus memasukan sebuah kata pada kotak paling atas. Berikut contoh tampilan kamus yang sudah diisi sebuah kata dapat dilihat pada gambar 8 . di bawah ini sebagai berikut :

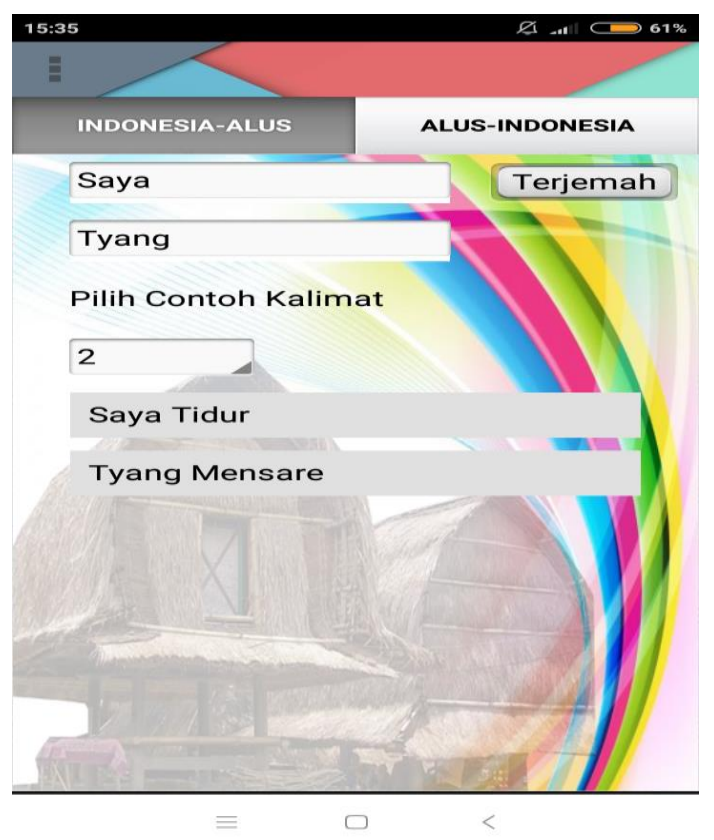

Gambar 8. Tampilan menu kamus 


\section{Tampilan Menu Mengelola Login}

Tampilan mengelola login merupakan tampilan dimana admin dapat menambah maupun meng hapus data, admin atau data login. Adapun tampilan interface mengelola login dapat dilihat pada gambar 9. di bawah ini sebagai berikut :

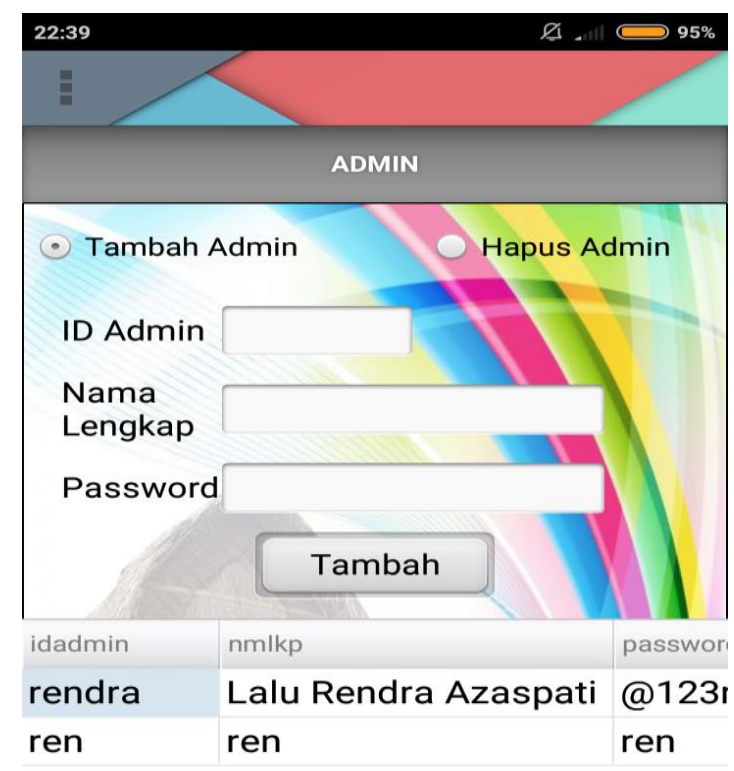

\section{E. Tampilan Tambah Kata Indonesia}

Admin harus mengisi data yang akan disimpan, ID Kata merupakan identitas kata yang tidak boleh sama dengan ID Kata yang lain, adapun tampilan tambah kata Indonesia dapat dilihat pada gambar 10. di bawah ini sebagai berikut :

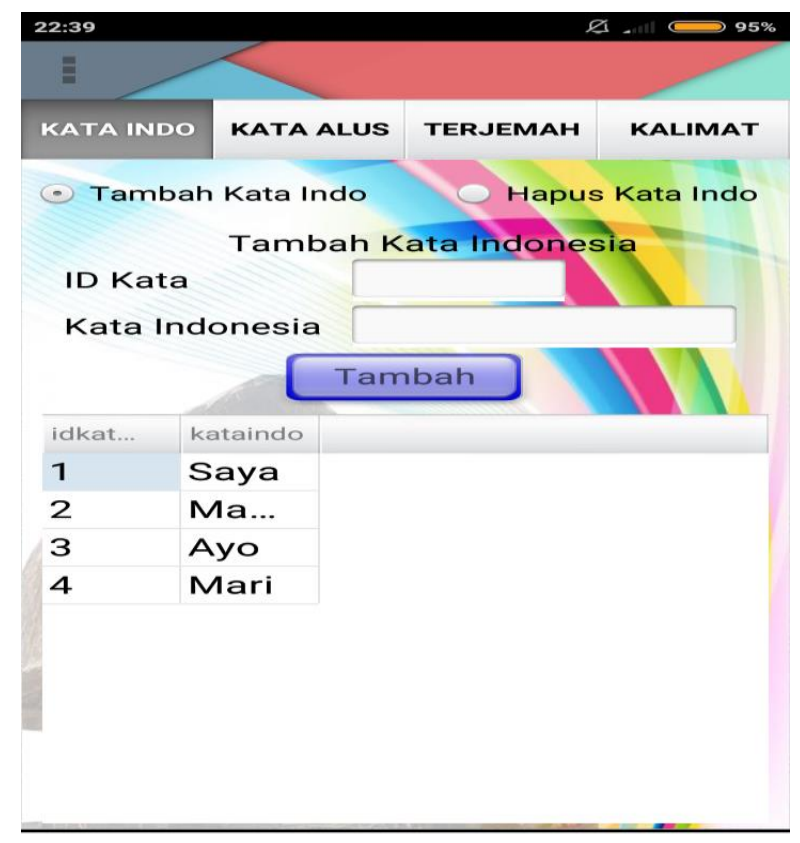

Gambar 10. Tampilan tambah kata Indonesia

\section{F. Tampilan Hapus Kata Indonesia}

Pada bagian tampilan hapus kata Indonesia, admin hanya mencari Kata Indonesia, Selanjutnya tekan tombol Hapus, adapun tampilan hapus kata Indonesia dapat dilihat pada gambar 11. di bawah ini sebagai berikut :

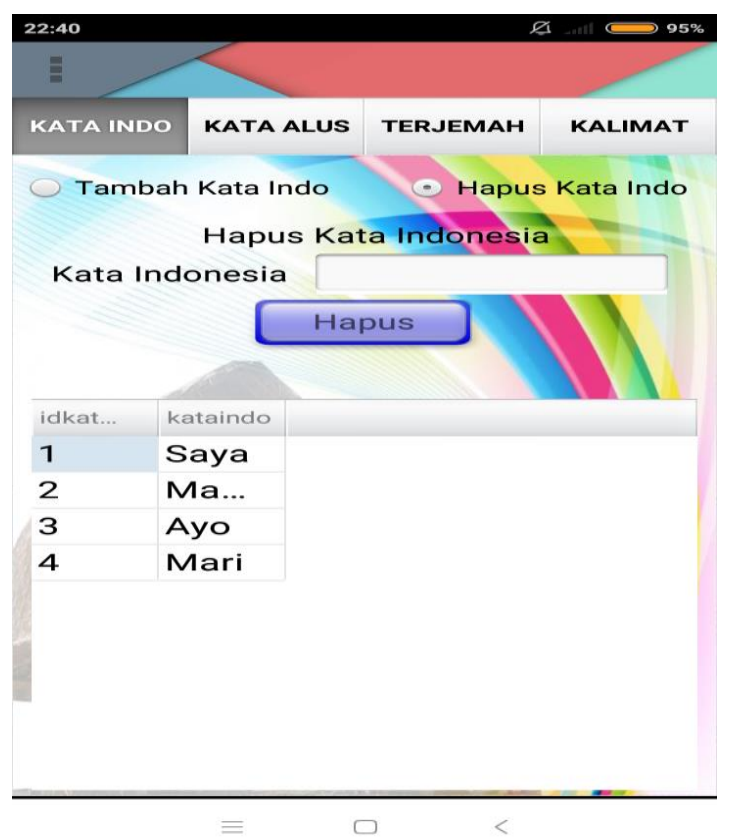

Gambar 11. Tampilan hapus kata Indonesia

\section{G. Tampilan Tambah Kalimat}

Tampilan tambah kalimat merupakan tampilan dimana admin dapat menambah kalimat. ID Kalimat merupakan identitas kalimat yang tidak boleh sama dengan ID Kalimat yang lain, adapun tampilan tambah kalimat dapat dilihat pada gambar 12. di bawah ini sebagai berikut : 


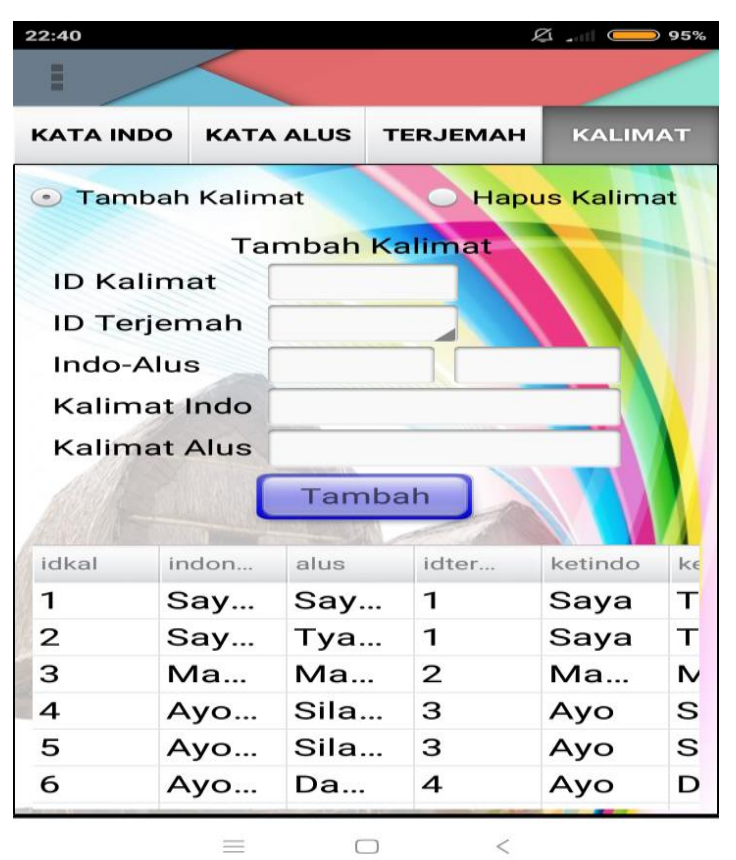

Gambar 12. Tampilan tambah kalimat

\section{KESIMPULAN}

Kesimpulan dari penelitian ini adalah:

1. Aplikasi sudah dapat digunakan sebagai media pembelajaran bahasa sasak.

2. Aplikasi bersifat user friendly dan dapat dijalankan pada smartphone dengan sistem operasi android minimal versi Froyo 4.0 ke atas.

3. Dengan adanya aplikasi kamus bahasa Sasak Halus berbasis android maka dapat mempermudah masyarakat lombok untuk lebih memperdalam bahasa sasak hususnya bahasa Sasak Halus, selain itu dapat digunakan oleh semua kalangan pelajar serta para wisatawan dalam belajar bahasa sasak.

4. Aplikasi kamus Bahasa Sasak Halus ini dapat menjadi media untuk mempelajari bahasa halus yang biasanya hanya sebagian orang yang memahami dan menggunakan bahasa Halus sasak untuk berkomunikasi.

\section{DAFTAR PUSTAKA}

[1] Wibowo, Wahyu. 2011. Cara Cerdas Menulis Artikel Ilmiah. Jakarta: Kompas.

[2] Ilhami, A., 2014. Rancang Bangun Aplikasi Kamus Bahasa Indonesia-Bawean Menggunakan Algoritma Best First Search (BFS). Jurusan Teknik Informatika Fakultas Sains dan teknologi. Universitas Islam Negri Maulana Malik Ibrahim Malang.

[3] Farida, I. N., 2014, Aplikasi Kamus Bahasa IndonesiaJawa Berbasis Android, Nusantara Of Engineering, ISSN: 2355-6684, Vol. 2, 2010.
[4] Fadlullah, M., 2011, Rancang Bangun Aplikasi Kamus Jerman-Indonesia Berbasis Android, Skripsi, Fakultas Teknologi Informasi, UNISBANK, Semarang.

[5] Keraf, Gorys. 2007. Diksi dan Gaya Bahasa. Jakarta: Gramedia Pustaka Utama.

[6] Wahana Komputer. 2013. Step by Step Menjadi Programmer Android. Yogyakarta: Andi.

[7] Satyaputra, Alfa. 2014. Begining Android Programming With ADT Bundle. Jakarta: Elex Media Komputindo. 